\title{
ローラー型自動現像機の現像因子について
}

\author{
金沢大学医学部付属病院放射線部 \\ 山本.喜代志・島 田裕 弘
}

（䜊文受付 昭和43年10月28日）

\section{ON THE FACTORS OF DEVELOPMENT IN A ROLLER TYPE AUTOMATIC PROCESSOR}

\section{By KiYOSHI YAMAMOTO \\ YASUHIRO SHIMADA}

From the department of radiology, Kanazawa University Hospital

(Article received : October. 28, 1968)

\section{Summary}

Development of films in a roller type automatic processor depends chiefly upon the temperature of developer, pressure of a roller, site of vomitory of a circulating pump, fatigue of fllter, and flow rate of replenisher.

So these factors were studied by examining density curve of films using an aluminium step penetrameter.

1) Similar density curves were obtained by CDM-101R developer at the temperature of $26.5^{\circ} \mathrm{C}$ for 1.5 minute in a roller type and by CDRX developer at $20^{\circ} \mathrm{C}$ for $2 \mathrm{~min}$. $40 \mathrm{sec}$. in a hanger type processor. Nevertheless, higher shadow density and lower $\gamma$, that is flatter tone of flm, were often revealed in the former.

2) Coincidence of density curves was observed in the following two cases, a roller was operated for 90 seconds in developer of an automatic processor, and ordinary 140 seconds development in a tank processor. This shows the fact that pressure for a roller promote development equally.

3) Agitation power was decidedly diminished by a solution roller rack, but, development of the part of film around vomitory was apparently increased, so "toe" or "shoulder" in density ourve were noted.

4) A developmental filter revealed about $1 \mathrm{gr}$ adherence after dealing 300 sheets of film in the size of $10 \times 12$ inches. Namely, no remarkable changes occur in density curve of films after development of 12,000 sheets of the same film.

5) Flow rate of replenisher must be smaller in the case of relative more percentage of films sized under $10 \times 12$ inches.

6) Avoidance from higher shadow density and flattening of film which in apt to be taken place in high temperature developing could be obtained by suitable combination of developer and film.

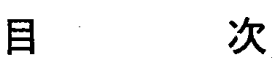

はじめに

I . 実験方法
II. 実験成績

1.ローラー型とハンガー型自動堄像機の現像効果

2. ローラーによる压迫と攪抖效果

3. 循環ポンプ噴出口位置の影響 
4. 循環ポンプ系液用フィルターの疲汅の影響

5. 補允の影響

6. 現像液の種類に上る影響

a ) CDM-101R と改良型 CDM-101R（CDM-101 $\mathrm{R}^{\prime}$ ) との比較

b ) 現像液と自動現像機およびフィルムの組合せ

III 総括ならび沉考按

むすび

参㜣文献

\section{はじめに}

白動現像機（以下自琴機と略ず）は1944年 Pako 社が

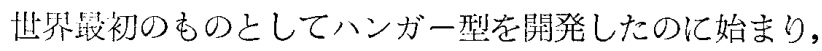
1960年にはローラー型7分処理のものを発表1している. Eastman Kodak 社は1951年ハンガー型工業用を，続い て1954年ローラー型工業用Xオートマットをモデル Aと して，翌1955年にはローラー型㗨療用モデル M1を， 1956年に M2，1957年には 7 分处型の M3 を，さらに 1960年曾及型 M4 と次々に改良品発表した1) 4)13)。 ま た Flema 社は1955年にハンガー型プロコマートを世に だした1). 英国 Nucleonic \& Radiological Development 社も1953年よりハンガー型を発売しはじめ2), Oscar Fisher 社は 7 分処理の FaX-Ray Processor を1959年に 発表している3). な挑画用フィルムに対しては1886年 Urie 親子が自現機のイギリス特許 No. 16327 をとって 以来数多くの叝尔3)5)6)がある. これに伴(現像の迅速化 には高温現像6) 8)や2洒のバナジウムの使用に伴う現像

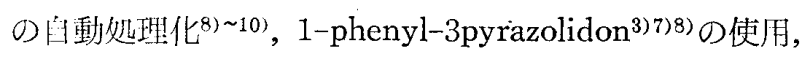
また, チ才硫酸アンモニウムの使用による定着の迅速 化711)扎よび水洗, 乾燥の迅速化 ${ }^{3) 7}$ の研究がされてきた。 このような内外の動きとは別に本学では松田の考案 ${ }^{15} に$ よる独兒のハンガー型自現機が東芝の成川らの協力で 1958年の試作を経て1959年 9 月に完成した。この場合の 現像は小西六の合田らにより 1-phenyl-3pyrazolidon を 主剤とした迅速晲像液と㩭抖ポンプによる㩭抖 $20^{\circ} \mathrm{C}, 2$ 分40秒, 減量補无方式で従来の Rendol や Conidol-X,

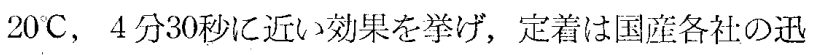
速起着液を用いた，水洗はオーバーフロー方式で $180 l$ の水槽に毎分 10〜13l の流量で14分間, 乾燥湿度30 $40 \%$ ，40〜 50 C に調節した温風の14分間吹きつけで行 なった. 勿諭ハンガー型であるための久点, 使用部品の 材貿，構造上の不䚚による故障は使田使月の経過ととも に熄抓の傾向があったが 1 日最高 500 枚までの処理は可 能であった．1964年10月ローラー型自現機の購入により
従来とは全く異なった日子が現像過程で加わるととが考 えられたので現像液とその補充，ローラーの王迫，攪挥 効果, 循環ポンプ噴出口位置, 現像液用フィルターの疲 労などについて比較検傠を加えた。

\section{I. 実 験 方 法}

同一条件で曝射したフィルムの濃度変化を基に実験を 進めるためX線発生装犆は島津製山城号 B-2 型で撮影 条件は $60 \mathrm{kVp}, 200 \mathrm{~mA}, 1 / 30 \mathrm{sec}, F F D$ は $100 \mathrm{~cm}$, 増感 紙は極光のFS を用いた。さくら X-レイフィルムに撮 影した Al 階段の濃度変化は東京光電製透過用濃度計で 測定した。 $\gamma$ は $\mathrm{Al}$ 階段の厚さ目盛に対する濃度 0.6 から 2.0 の部分の傾斜角で求めた。

\section{II. 実 験 成 績}

\section{1. ローラー型とハンガー型自現機の現像効果}

\section{目的及び方法}

まず東芝製ハンガー型自現機ではCDRX現像液の $20^{\circ} \mathrm{C}$, 2 分40秒で現像していたフィルムを，さくら X-レイロ ーラー型自現機で CDM-101R 現像液の90秒現像にその まま移行するのに必要な現像温度の決定を試みるために 現像温度は $26,27,28,28.5^{\circ} \mathrm{C} の 4$ 種として比較検討し た.

\section{結果}

第1-a図のどとくハンガー型自現機，CDRX, $20^{\circ} \mathrm{C}, 2$ 分40秒現像の濃度曲線の低濃度部は口ーラー型自現機, $\mathrm{CDM}-101 \mathrm{R} 26^{\circ} \mathrm{C}$ 処理の低濃度部之, 高濃度部は $27^{\circ} \mathrm{C}$ のものに近似したものとなっている. Shadow density (ベース濃度＋カブリ值)はCDRX の0.12 亿対し CDM$101 \mathrm{R} 26^{\circ} \mathrm{C}$ は $0.14,27^{\circ} \mathrm{C}$ では 0.16. rは 1.48 に対し $26^{\circ}$ $\mathrm{C}$ で $1.3,27 \mathrm{C}$ では 1.45 となった。 また口ーラー型自現 機, CDM-101R の各濃度曲線を $\mathrm{Al}$ 階段 $3 \mathrm{~mm}$ どとの 現像温度濃度曲線に変換し, ハンガー型自現機, CDRX, $20^{\circ} \mathrm{C}, 2$ 分 40 秒現像の濃度曲線己比較したものが第 $\mathrm{i}-\mathrm{b}$ 図である．診断に有效な濃度D 2.0 以下について考え ると CDRX 現像液使用時に近い效果が得られる。

しかし Shadow densityの高くなるととは免れない.

\section{2. ローラーによる圧迫と掜拌効果}

\section{目的及び方法}

ローラー型自現機は従来から行なわれている皿やタン ク現像の場合と異なり，ローラーによる圧迫と現像速度 関係，およびハンガー型自現機にも認められた攪找によ る現像の進行が予測される。それでさくら X-レイ自現 機を，1）現像液用ラックを除き，攪排ポンプを停止し 


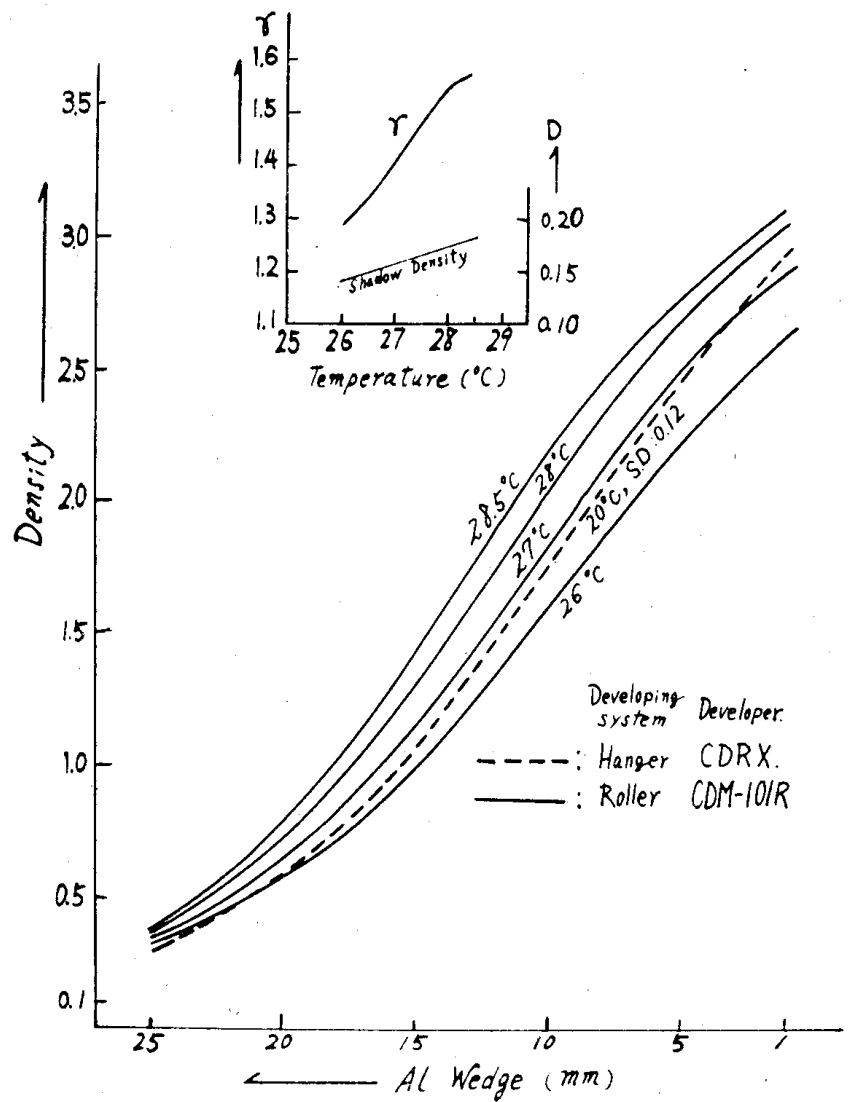

Fig. 1-a Relationship between density curves and developmental temperature of roller-type automatic processing at $20^{\circ} \mathrm{C}, 2^{\prime} 40^{\prime \prime}$.

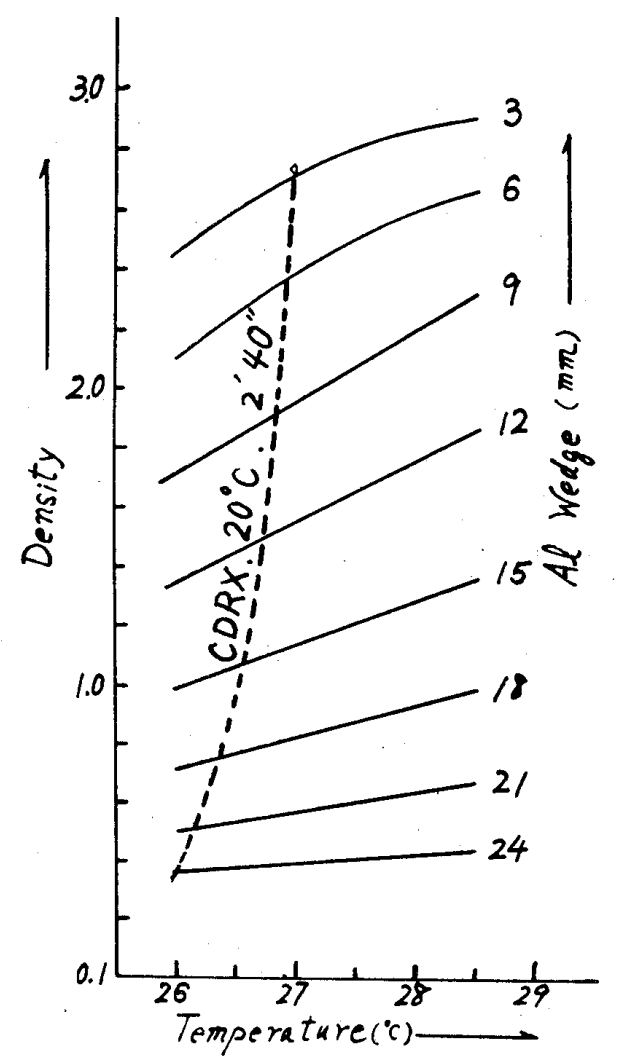

Fig. 1-b Temperature-density curves of ALstep penetrameter at the roller-type automatic processing.

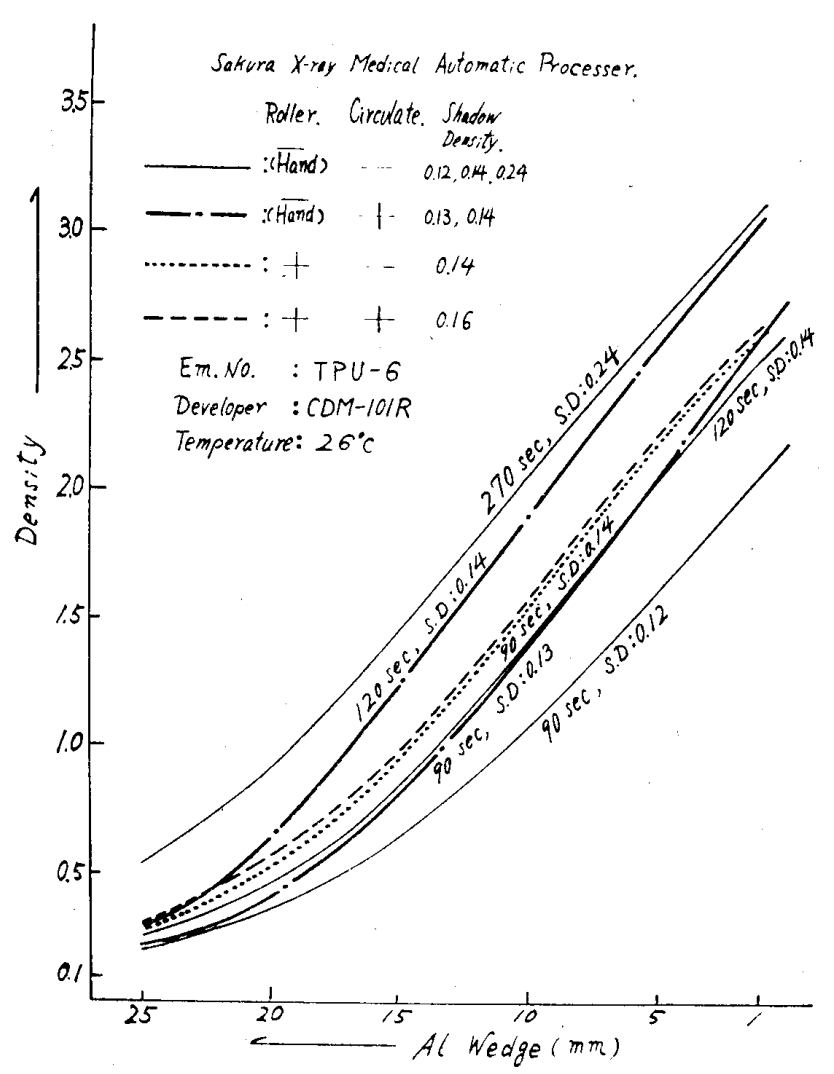

$\leftarrow$ Fig. 2-a The variation of density curves due to pressure of roller and agitation at the film, in an automatic processer.

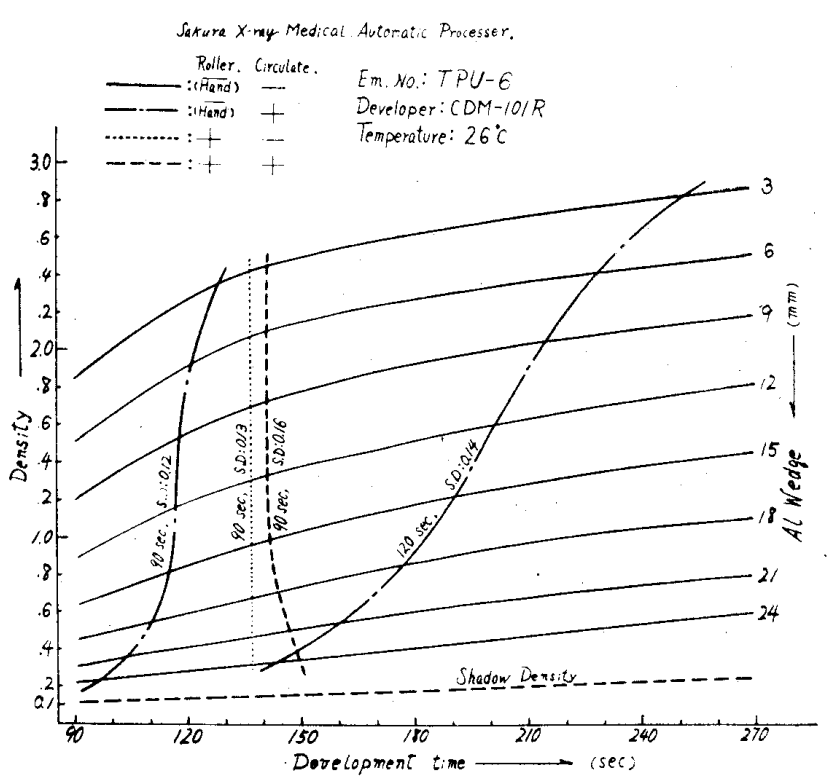

Fig. 2-b Density-development-time-curves. (A comparison of density curve with pressure of roller and agitation to films). 
$1.5 ， 2.0 ， 4.5$ 分現像．2）現像液用ラックを除さ，攪挥 ポンプを駆動して $1.5 ， 2.0$ 分現像. 3) 現像液用ラック

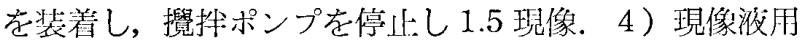
ラック装着，攪挥ポンプ駆動時の 1.5 分現像による浱度 曲線を比較した。

\section{結果}

それぞれの濃度曲線は第2-a 図化示すごとく，現像淮 用ラック装着, 攪排ポンプ停止時（点線）と駆動時（破 線）の濃度曲線は低濃度部以外はほとんど差を認めない。 また攪排ポンプ停止 2 分現像（実線）と攪排ポンプ駆動 1.5分現像 (一点鎖線) は濃度 2.0 五ら濃度 1.0 の範用で は一致するが，低濃度部の濃度 1.0 以下では灚排 1.5 分 現像の方が低い。乙れら相互の関係を求好るた好㩭抖 ポンプ停止時の各濃度曲線を $\mathrm{Al}$ の厭さ $3 \mathrm{~mm}$ ごとの現 像時開濃度朋線上で齐現像因子别に比較したのが第 2-b 図である，現像液用ラック装着，攪排ポンプ停止 1.5 分 (点線)では直線となり，攪拌ポンプ停址タン現像の 137 秒に相当しローラーの压迫は各濃度部沟等作㓅 し約50秒の現像时間延長にひとしい効果を衣している。 攪扑ポンプ駆動·(破線)により濃度 0.9 以上の部分はさ らに約 5 秒延髟したのにひとしい浱度となるが浱度 0.9 以下では低濃度部ほど現像の進行が著しく，Al $24 \mathrm{~mm}$ の部分では 150 秒，すなわち60秒の現像洔閻延辰に相当 する濃度の上昇を示している。また㩭挥現像 (一点鎖線) では高濃度部ほど現像の進行は著しく，現像時閌の辰い ほどその差が著しくなる。乙の現象から CDM-101R 現 像液でも噴流㩭抖效果は高照度上なる活どく現われるが， 液间ラックの装着で極度に弱められることが判时した。

\section{3. 循環ポンプ噴出口位置の影響}

\section{目的及び方法}

第2-b図の破線汇認められた攪扑ポンプの龂動で低濃

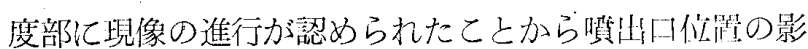
響が考えられるので嘪出口側に $\mathrm{Al}$ 階段の犀い部分，す なわち低照度側を置いて現像した場合と逆に高照度側を 罳いた場合の濃度变化を当院設置のさくらXーレイ向現 機 $1 ， 2$ 号機沉つて比較検剖した。

\section{結果}

循環ポンプ貲出口位置の影響を 2 台の自现機について 比較したすのが第 3-a 図であり，2号機だけについて 1 カ月の間隔を経て比較したものが第 3-b図である。高照 度部を噴汁口側㯰いたものを奏線で，逆低低照度部を 置いたむのは破線で示した。いずれの場合む父点は一定 しないが契線と破線はむる点で交わり濃度曲線の雨端に なるほど差を生じている，乙の浱度曲線を変換した現像
㭙間濃度曲線上で比較すると，1号機 (No. 1) で覺汼 ポンプを停止したときの濃度曲線（一点鎖線）は第 2-b 四の点線同様直線となる。実線の $\mathrm{Al} 24 \mathrm{~mm}$ の部分は濃 度 0.3 で 138 秒， $\mathrm{Al} 3 \mathrm{~mm}$ では濃度 2.54 で 159 秒に相 当する現像の進行を示しているのに対し，破線では同じ 部分が濃度 0.34 で 162 秒, 濃度 2.52 で 154 秒 となり, $\mathrm{Al}$ $5.5 \mathrm{~mm}$ 濃度 2.20 の点で交差している，同様に 2 罗機 (No. 2) の㬰線は浱度 0.21 で97秒，濃度 2.25 では 120 秒となり，破線では濃度 0.25 で 125 秒，濃度 2.20 で115 秒に相当する現像の進行を示し， $\mathrm{Al} 5 \mathrm{~mm}$ ，濃度 2.0 の 点で交差している，再現性を求めるために 2 号機につい て行なったものが第3-bで2月20日の実線の場合は $\mathrm{Al}$ $24 \mathrm{~mm}$ の部分は濃度 0.26 で 104 秒， $\mathrm{Al} 3 \mathrm{~mm}$ では濃度 2.24 で 122 秒となったのに対し破線の場合は濃度 0.28 で 124 秒，濃度 2.20 では 114 秒となり Al $9.5 \mathrm{~mm}$ ，淽 度 1.4 で交差し，3月22日の堄挥ポンプ停止，ローラー の圧迫のみでは前記の奏験同様現像時間浱度曲線に刘し 直線となり，循環ポンパ駆動，噴出口側汇高照度部艺罚 いた実線の場命は Al 24mm の部分は濃度 0.19 で 117 秒， $\mathrm{Al} 3 \mathrm{~mm}$ では濃度 2.24 で 124 秒，低照度部を罟い た破線の場合は $\mathrm{A} l 24 \mathrm{~mm}$ の部分は濃度 0.23 で 126 秒, $\mathrm{A} l 3 \mathrm{~mm}$ の部分では濃度 2.18 で 113 秒のタンク現像の 濃度に相当し，Al 16mm. 濃度 0.65 の点で交差してい 万。

すなわち高照度，低照度側のいずれの部分でも泪環ボ

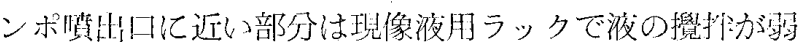
められてはいるが明らかに，をの影響を受けているため に部分的な濃度上显走示すもの上考えられる。乙机を留 約する己 $\mathrm{Al} 24 \mathrm{~mm}$ の低照度部老哢出口汇近つけた埸合 と離した場合を比較すると濃度の変化幅は小さいが約25 秒に相当する現像の進行汇差を生じ， $\mathrm{Al} 3 \mathrm{~mm}$ の高照度 部では濃度幅は 0.5 前後で約15秒汇相当行る現像の進行 汇差を生じた。

\section{4. 循環ポンプ系液用フィルターの疲労の影響}

\section{目的及び方法}

液用フィルターが現像液巾の酸化生:成物，浴解銀，ゼ ラチンなどを吸着滤過するためのすので少るなら当然使

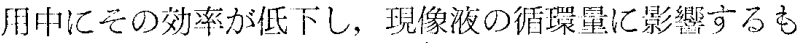
のと若えフィルタ一使用前後における重基の变化と，天 の時期の濃度曲線，現像フィルム枚数よりフィルターの 秛斿を検䚯した。

\section{結 果}

炤和39年11月より40年 3 月までの約 5 力月開汇现像し たフィルム枚数と，サイズの関係は第 1 表のごとくなり， 

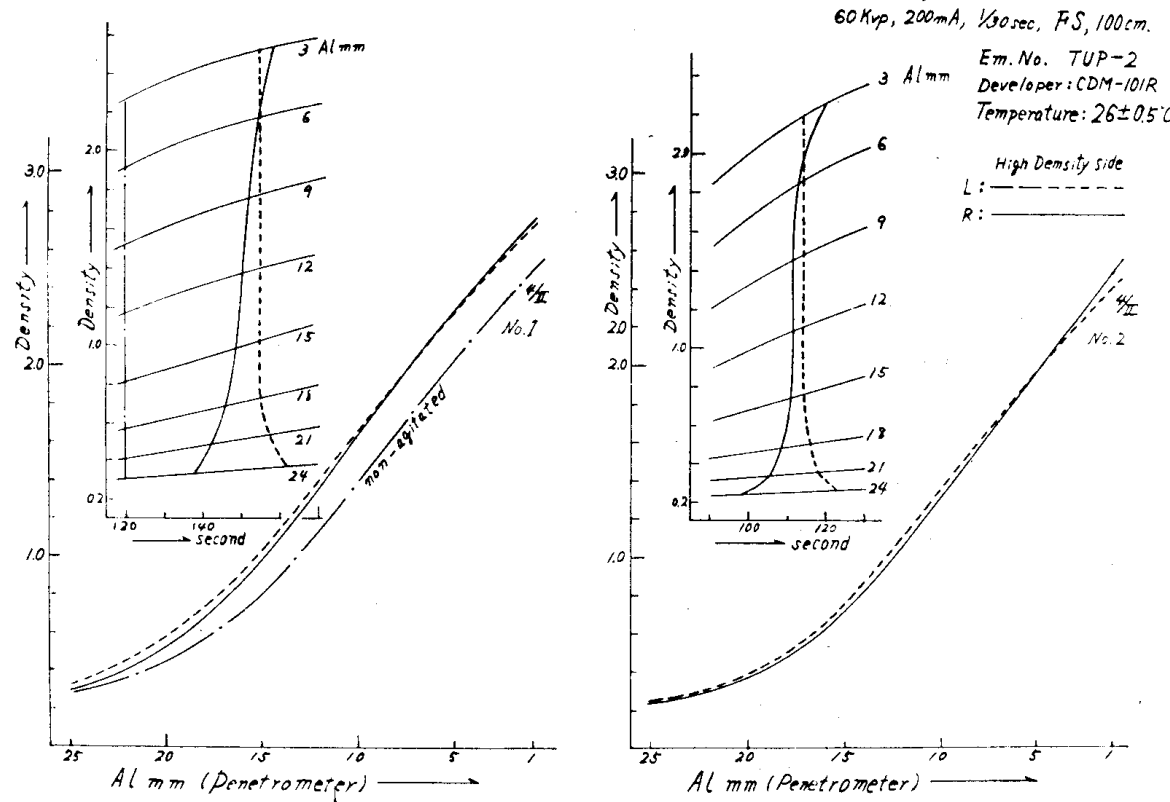

Fig. 3-a Influence of the site of vomitory on density curves of a Films. (compared with the automatic processer No. 1 and No. 2).
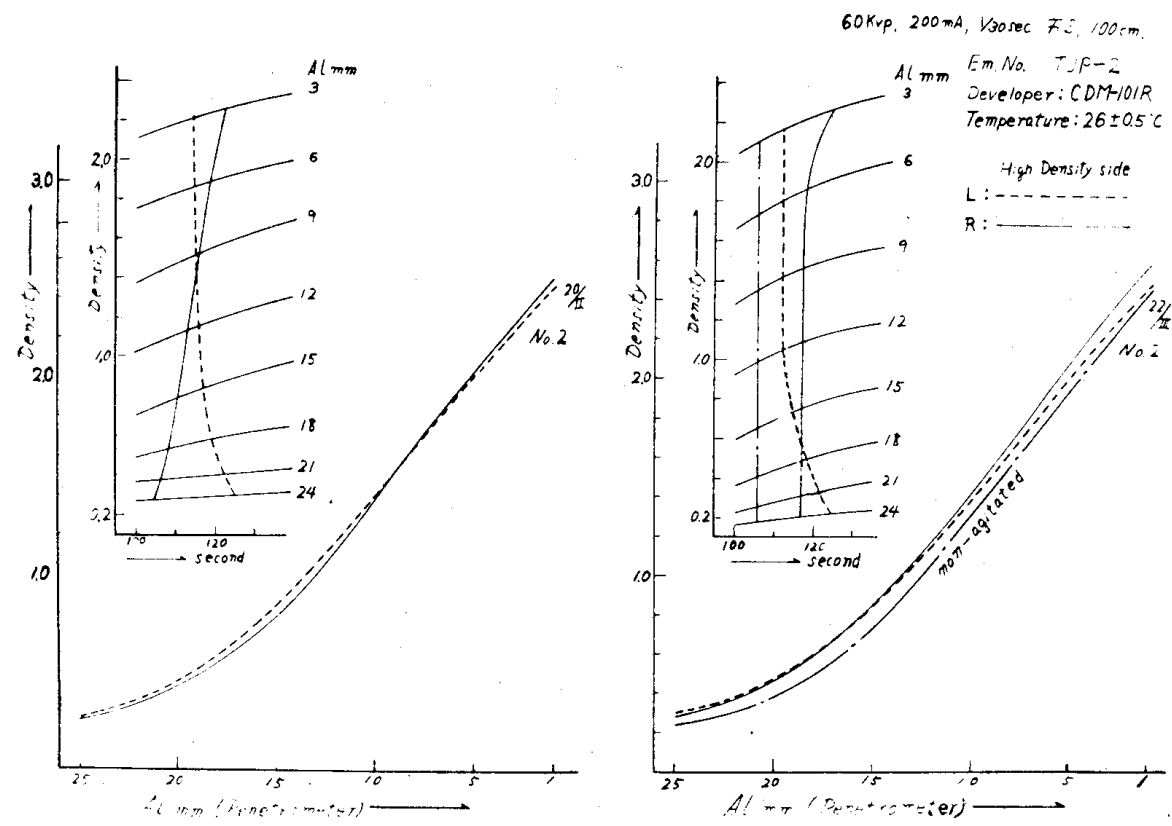

Fig. 3-b Influence of the site of vomitory on density curves of a films. (compared during $20 / \Pi$ and $22 / \Pi I$, 1965, at the automatic processer No. 2).
1 宁機では四ツ划換算 17,241 枚, 2 号機は18,022枚となった。各 自現機の使用開始前のフィルタ 一乾燥時重量は $45.1 \mathrm{~g}$ 乙 $45.3 \mathrm{~g}$ で使用打切り後湿度55～75\%の 窒内で自然乾燥10日以後平均重 量は $95.2 \mathrm{~g}$ と $113 \mathrm{~g}$ となり, 第 2 表のごとくいずれむ使用前の 倍以上の重さとなっている。乙 のような重量変化の前後におけ る濃度此線の変化を第 4 図のご とく自現機の噴出口側に高照度 部 $(\mathrm{H})$ を置いた場合と低照度部 （L）を䈯いた場合を比較すると フィルターの使用開始時のむの (実線) は使用打切時のもの(破 線）に比し，1号機では H， L いずれも10数秒の現像時間短縮 に相当する避れを生じている。 また循環ポンプ噴出口位置の影 響はフィルターの使用時期に関 係なくいずれの場合にも認めら れた. この現象汃ら現像液用フ イルターの疲労, すなわち目づ まりによる重量の増加が 2 倍程 度では噴出四位置での噴出量に 大きな影響が生じていないと考 えられる。換言するとフィルタ 一の取換え間隔が四ツ切フィル 么換算 20,000枚程度までなら現 像効果に大きな影響はないと言 える。なおフィルターの重量増 加は 1 号機では四ツ切フィルム 344 枚，2 号機では266枚で $1 \mathrm{~g}$ ， 平均 300 枚で $1 \mathrm{~g}$ となる，反面つ イルターの使用にあかかわらず

Table 1. Number of films developed during period from Nov. 7, 1964 to March 28, 1965.

\begin{tabular}{|c|c|c|c|c|c|c|c|c|c|c|}
\hline \multicolumn{3}{|c|}{ Film size (inch) } & $14 \times 14$ & $11 \times 14$ & $10 \times 12$ & $8 \times 10$ & $61 / 2 \times 81$ & $3 / 4 \times 61 / 2$ & Total & $\underset{\%}{\text { Ratios }}$ \\
\hline \multirow{2}{*}{$\begin{array}{c}\text { Automatic } \\
\text { processer } \\
\text { Number }\end{array}$} & 1 & $\begin{array}{c}\text { number } \\
\text { Conversion } 10 \times 12^{\prime \prime}\end{array}$ & $\begin{array}{l}1,774.0 \\
2,909.36\end{array}$ & $\begin{array}{l}4,896.0 \\
6,315.84\end{array}$ & $\begin{array}{l}5,49 \\
5,49\end{array}$ & $\begin{array}{l}3,7 \\
2,4\end{array}$ & $\begin{array}{r}124.0 \\
61.64\end{array}$ & 2 & $\begin{array}{l}16,059.0 \\
17,241.32\end{array}$ & 100 \\
\hline & 2 & $\begin{array}{c}\text { number } \\
\text { Conversion } 10 \times 12^{\prime \prime}\end{array}$ & $\begin{array}{l}1,365.0 \\
2,238.60\end{array}$ & $\begin{array}{l}3,708.0 \\
4,783.82\end{array}$ & $\begin{array}{l}7,179.0 \\
7,179.0\end{array}$ & $\begin{array}{l}5,541.0 \\
3,657.02\end{array}$ & 133.4 & $\begin{array}{c}119.0 \\
30.94\end{array}$ & $\begin{array}{l}18,202.0 \\
18,022.32\end{array}$ & 104. \\
\hline
\end{tabular}



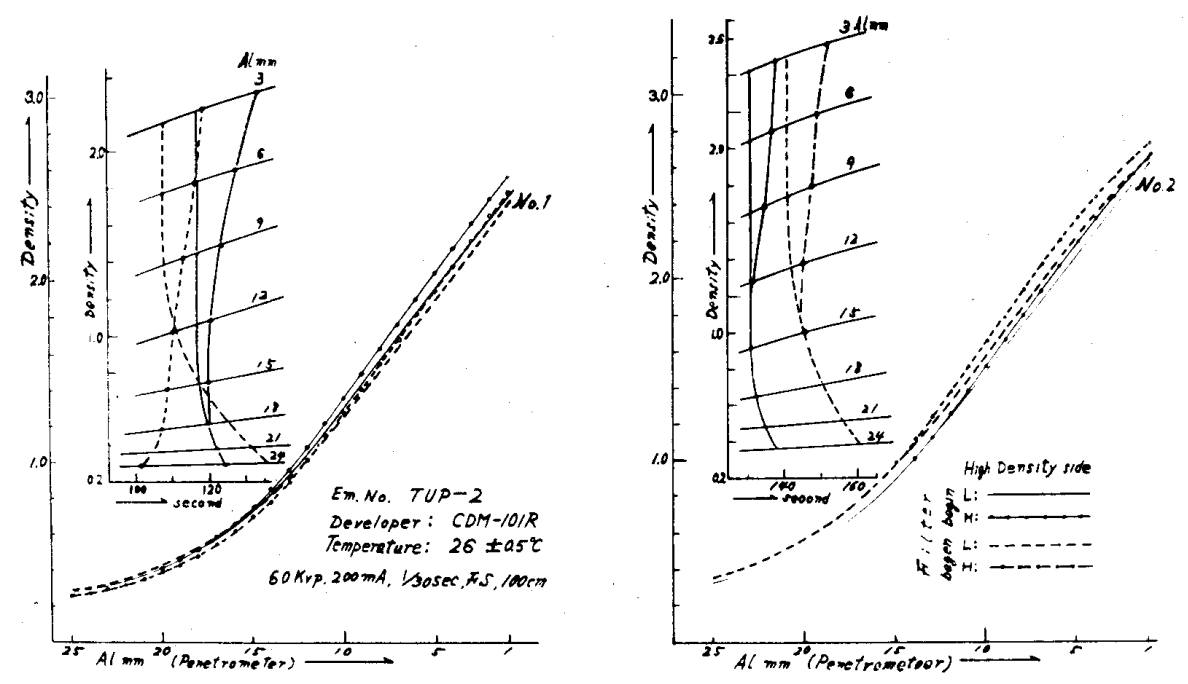

Fig. 4 Fatigue of developing-filter and variation of density curve.

量を求める係数を算出した，3) 1),2）で求めた係数で任意の 期間における現像フィルム枚数 とサイズ別の関係，及び補充液 量とその間のフィルム濃度曲線 を比較検討するとととした。

\section{結 果}

1）八ンガー型自現機使用中 の半年間の資料から 1 日の処理 枚数 200 枚以下. 300 枚以下. 400 枚以下は略して 400 枚以上 の 3 群を各 5 例ずつ抽出し,さ くらXーレ自現機のフィルム挿 入台幅が14时であることからフ イルムサイズ別の分類は $11 \times 14$
Table 2. The change of weight of filters (during use).

\begin{tabular}{|c|c|c|c|}
\hline & \multicolumn{3}{|c|}{ Automatic Processer } \\
\hline & Number & 1 & 2 \\
\hline $\begin{array}{l}\text { Dry weight } \\
\text { of Filter }(\mathrm{g})\end{array}$ & $\begin{array}{l}\text { before use } \\
\text { after use } \\
\text { Ratios } \%\end{array}$ & $\begin{array}{c}45.1 \\
95.2 \\
211.0(100)\end{array}$ & $\begin{array}{c}45.3 \\
113.0 \\
249.4(118.1)\end{array}$ \\
\hline
\end{tabular}

現像液槽の内壁, 現像液用ラックなどに酸化生成物や溶 解銀，ゼラチンなどが付着，沈澱するととから晲在使用 中のフィルターの効率は必ずしむ淽足すべきすのとは言 旮ない。

\section{5. 補充の影響}

\section{目的及び方法}

フィルムの自動処理化はシネフィルムの方が㷊史的に 古いが，フィルムサイズは一定していて問題はない。一 方，医療用の場合は使用フィルムのサイズは多様であり， またサイズ別の処理数量も事前には予測できないのが実 状である. それで，1 ) ハンガー型自現機使用期間中の資 料を基と日々の現像枚数とフィルムサイズの実態を求め ることとした.フィルムサイズが一定であれば強制補充 法と, 減量補充法のいづれでも現像液の管理の点では問 題は少ないが医療用フィルムを本自現機で処理する場合 は，フィルムが検出ラックを通過する間だ忖補充液が流 入する強制補充法であるし，使用フィルムサイズは一定 しないため現像液の疲労と現像液の補亣との間の平衡が 保ちにくくなるととが予測できる。よって，2）各サイ ズのフィルムが検出ラックを通過する時間と，フィルム の幅の違いから生ずる補充液の流入量と過剩補充になる
吋以上を $\mathrm{A}$ 群， $11 \times 12$ 村以以下を $\mathrm{B}$ 群任分類すると第 3 表のごとくなった。すなわち 1 日の処理枚数 200 枚以下 のときのA群は平均 $30.6 \% ， 300$ 枚以下では $35.7 \% ， 400$ 枚以上では $35.8 \%$ 上 1 日の処理枚数が増す活よ゙A群の上 める割合李增す傾何化ある。また逆にB群中で $8 \times 10$ 吋 フィルムの割命は48.01\%，37.82\%，36.44\%と処理枚数 が増す活ど減少している。

2) (1)フィルム送り速度の毎分 $460 \mathrm{~mm}$ に対する各サ イズのフィルム送り長さの比を補充係数 KL. (2)フィル ム挿入口幅 14 吋に対し $10 \times 12$ 吋以下のフィルムB群で は各サイズによりそれぞれ個有の空白部が生ずる。この 14吋一各フィルムの幅/14时を筀白部係数 KW. (3)補古 係数 $\mathrm{KL}$ 亡空白部係数 $\mathrm{KW} の$ 積を過剩補充係数 KL. $\mathrm{KW}$. (4)空白部係数 $\mathrm{KW}$ に対する補古係数 $\mathrm{KL}$ の比 $\mathrm{KW} / \mathrm{KL}$ を過剩補允比と名付けそれぞれのサイズ別に 求めたすのが第 4 表である.

3) これらの係数を用いて $1 ， 2$ 号機の各期間ごとの 処理枚数をサイズ別に計算したものが第 5 表a（1号機） 同表 b ( 2 号機)である. 各時期の毎分補光液流量と補允 量, 現像フィルム枚数に対するB群 $10 \times 12$ 吋以下の比之 過剩補允比, 各時期の濃度曲線中のAL 6. 15, 23mm の 部分の濃度とShadow density の関係を 1 号機は実線, 2 号機は破線でホすをと第 5-a図のごとくなった。この第 4 表 $\mathrm{a}, \mathrm{b}$ 亿見られるように観察期間が全く不規則な任 意の日数では現像フィルム数とサイズの間に一定の関係 を兒出せなかった．また第5-aで 27/10から 5/12 の間 は $1 ， 2$ 号機とす使用開始直後で流量計の調節，特に室 温，液温によるビニール管の軟化によるビンチコックの 生力変化に応じた調整が不光分で結果的に補克不足とな 
Table 3. Percentage of films in daily use. (observation period : April. 1-September. 30, 1965).

\begin{tabular}{|c|c|c|c|c|c|c|c|c|c|}
\hline . & Datum & Film Size & $14 \times 14$ & $11 \times 14$ & $10 \times 12$ & $8 \times 10$ & $81 / 2 \times 61 / 2$ & $42 / 3 \times 61 / 2$ & Total \\
\hline \multirow{15}{*}{$\begin{array}{l}\text { Cases in which a } \\
\text { small number of } \\
\text { film was treated. }\end{array}$} & \multirow{3}{*}{$1 / \mathrm{N}$} & $\begin{array}{l}\text { Number of film } \\
\text { used (sheet) }\end{array}$ & 2 & 51 & 45 & 73 & 8 & 0 & 179 \\
\hline & & \multirow{2}{*}{$\begin{array}{l}\text { Parcentege of } \\
\text { frequency }(\%)\end{array}$} & $1 . \overline{12}$ & 28.49 & 25.14 & 40.78 & 4. 47 & - & \multirow[t]{2}{*}{100} \\
\hline & & & \multicolumn{2}{|c|}{29.61} & \multicolumn{4}{|c|}{70.59} & \\
\hline & \multirow{3}{*}{$4 / \mathrm{IV}$} & No. (sheet) & 12 & 35 & 54 & 52 & 3 & 3 & 159 \\
\hline & & \multirow{2}{*}{$\%$} & 7.55 & 22.01 & 33.96 & 32.70 & 1.89 & 1.89 & \multirow{2}{*}{100} \\
\hline & & & \multicolumn{2}{|c|}{29.56} & \multicolumn{4}{|c|}{70.44} & \\
\hline & \multirow{3}{*}{$16 / \mathrm{V}$} & No. (sheet) & 6 & 40 & 44 & 69 & 3 & 2 & 164 \\
\hline & & \multirow{2}{*}{$\%$} & 3.66 & 24.39 & 26.83 & 42.07 & 1.83 & 1.22 & \multirow{2}{*}{100} \\
\hline & & & \multicolumn{2}{|c|}{28.05} & \multicolumn{4}{|c|}{71.95} & \\
\hline & \multirow{3}{*}{$20 / \mathrm{VI}$} & No. (sheet) & 5 & 54 & 65 & 50 & 1 & 0 & 175 \\
\hline & & \multirow{2}{*}{$\%$} & 2.86 & 30.86 & 37.14 & 28.57 & 0.57 & - & \multirow{2}{*}{100} \\
\hline & & & \multicolumn{2}{|c|}{33.72} & \multicolumn{4}{|c|}{66.28} & \\
\hline & & No. (sheet) & 10 & 48 & 78 & 42 & 3 & 0 & 181 \\
\hline & $14 / \mathrm{VII}$ & $\%$ & 5.53 & 26.52 & 43.09 & 23.20 & 1.66 & - & 100 \\
\hline & & 10 & 32. & 05 & & & 95 & & 100 \\
\hline & & No. (sheet) & 29 & 64 & 115 & 72 & 4 & 5 & 289 \\
\hline & $9 / \mathrm{N}$ & $\%$ & 10.04 & 22.15 & 39.79 & 24.91 & 1.38 & 1.73 & 100 \\
\hline & & 10 & 32. & 19 & & 67. & 81 & & 100 \\
\hline & & No. (sheet) & 21 & 70 & 101 & 70 & 22 & 1 & 285 \\
\hline & $21 / \mathrm{V}$ & $\%$ & 7.37 & 24.56 & 35.44 & 24.56 & 7. 72 & 0.35 & 100 \\
\hline Cases in which the & & -1 & 31. & 93 & & 68. & 07 & & \\
\hline number of treated & & No. (sheet) & 16 & 92 & 100 & 64 & 6 & 1 & 279 \\
\hline of films was almost & $18 / \mathrm{V}$ & $\%$ & 5.74 & 32.97 & 35.84 & 22.94 & 2.15 & 0.36 & 100 \\
\hline average. & & & 38. & 71 & & 61. & 29 & & \\
\hline & & No. (sheet) & 42 & 71 & 92 & 63 & 7 & 3 & 278 \\
\hline & $27 / \mathrm{VII}$ & $\%$ & 15.11 & 25.54 & 33.09 & 22.66 & 2.52 & 1.08 & 100 \\
\hline & & & 40. & 65 & & 59. & 35 & - & 100 \\
\hline & & No. (sheet) & 13 & 83 & 100 & 72 & 2 & 3 & 273 \\
\hline & $20 / \mathrm{VII}$ & $\%$ & 4.76 & 30.40 & 36.63 & 26.38 & 0.73 & 1.10 & 100 \\
\hline & & 1 & 35. & 16 & & 64. & 84 & & \\
\hline & & No. (sheet) & 31 & 126 & 172 & 118 & 14 & 4 & 465 \\
\hline & $4 / \mathrm{IV}$ & \{ & 6.67 & 27.10 & 36.99 & 25.37 & 3. 01 & 0.86 & 100 \\
\hline & & 1. & 33. & 77 & & 66. & & & 100 \\
\hline & & No. (sheet) & 35 & 114 & 127 & 110 & 28 & 1 & 415 \\
\hline & $19 / \mathrm{V}$ & $\{-$ & 8.43 & 27.47 & 30.60 & 26.51 & 6.75 & 0.24 & 100 \\
\hline & & $\%$ & 35 . & 90 & & 64. & 10 & & 100 \\
\hline Cases in which a & & No. (sheet) & 31 & 131 & 168 & 85 & 6 & 2 & 423 \\
\hline great of number of & $2 / \mathrm{VI}$ & $\%$ & 7.33 & 30.97 & 39.72 & 20.09 & 1. 42 & 0.47 & 100 \\
\hline films was treated. & & & 38. & 50 & & 61. & 70 & & \\
\hline & & No. (sheet) & $36^{\circ}$ & 109 & 178 & 95 & 8 & 3 & 429 \\
\hline & $23 / \mathrm{VII}$ & $\%$ & 8.39 & 25.41 & 41. 49 & 22.15 & 1.86 & 0.70 & 100 \\
\hline & & & 33. & 80 & & 66. & & & \\
\hline & & No. (sheet) & 34 & 119 & 162 & 95 & 3 & 0 & 413 \\
\hline & $25 / \mathrm{VII}$ & $\%$ & 8.23 & 28.81 & 39.23 & 23.00 & 0.73 & - & 100 \\
\hline & & 0 & 37. & 04 & & 62. & & & \\
\hline
\end{tabular}




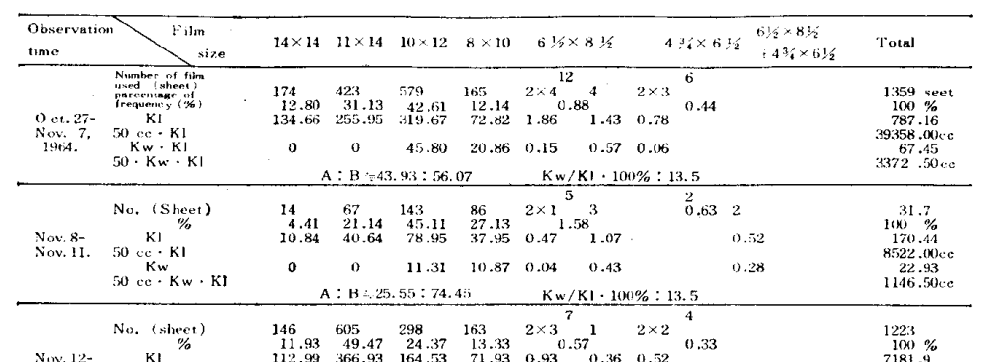

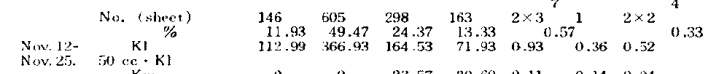

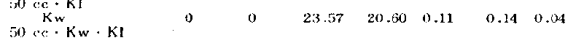

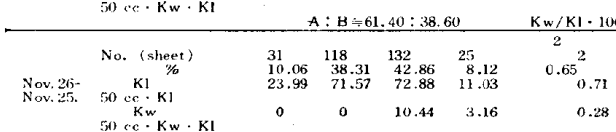

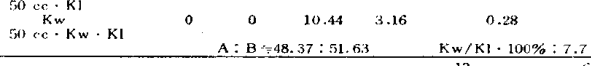

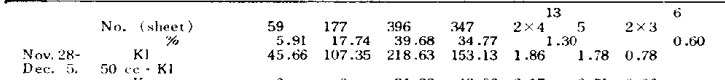

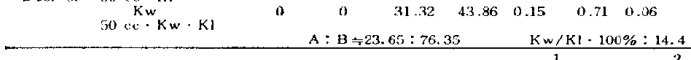

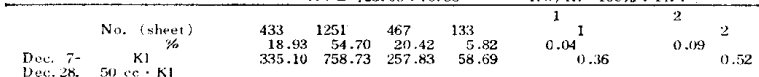

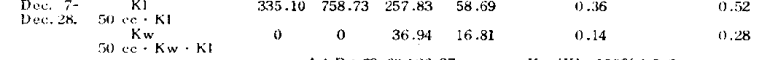

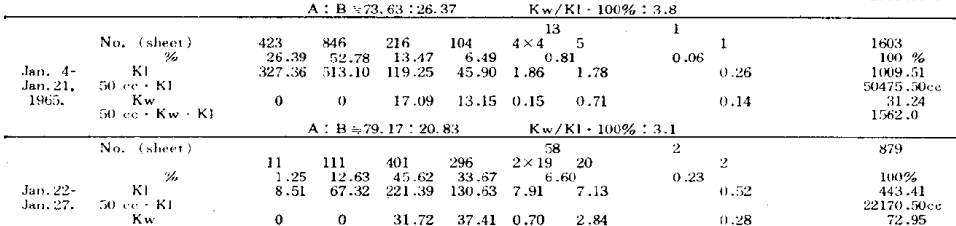

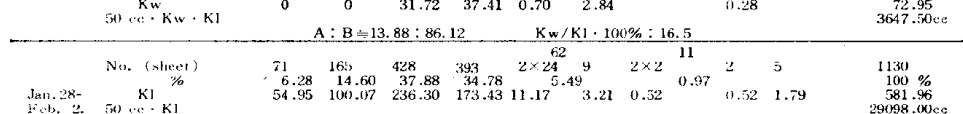

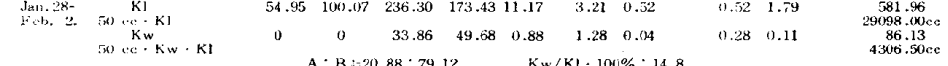

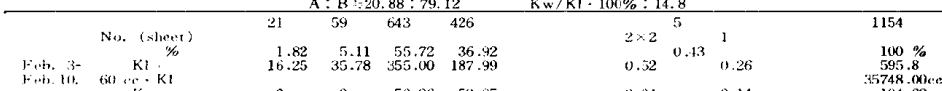

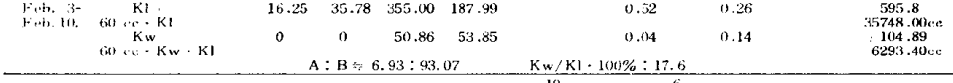

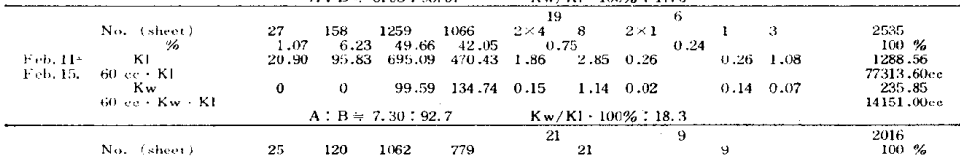

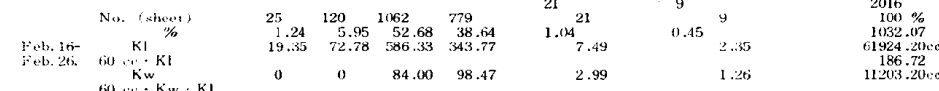

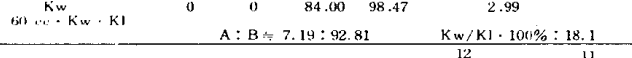

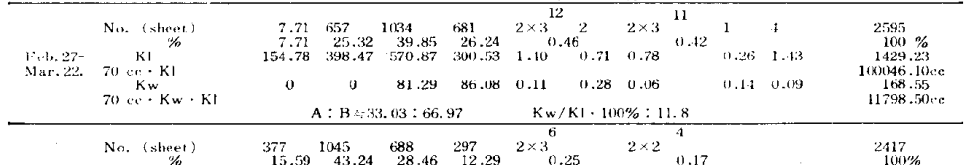

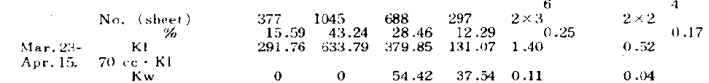

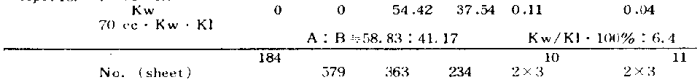

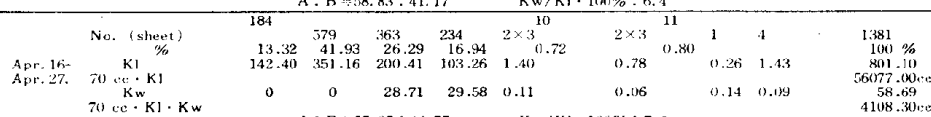

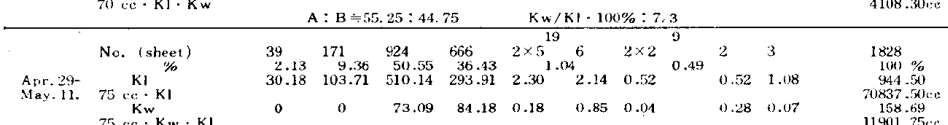

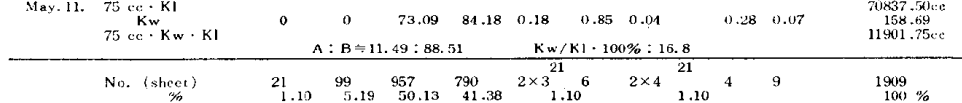

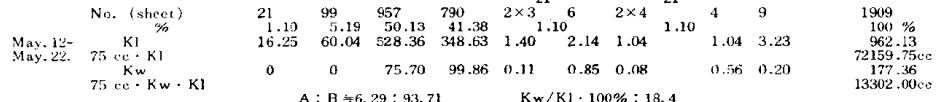

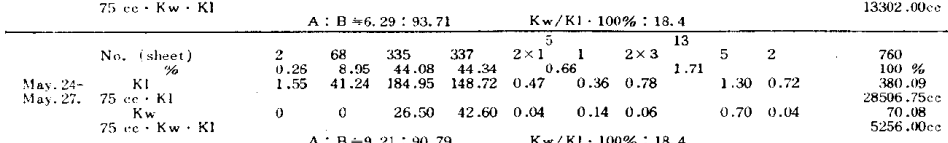

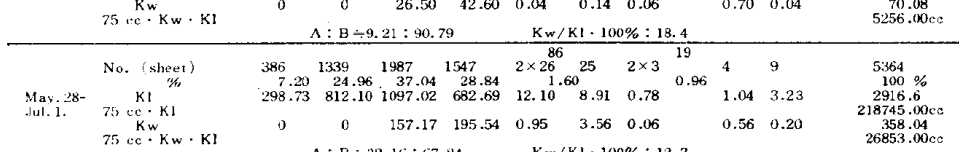
Table 5-a

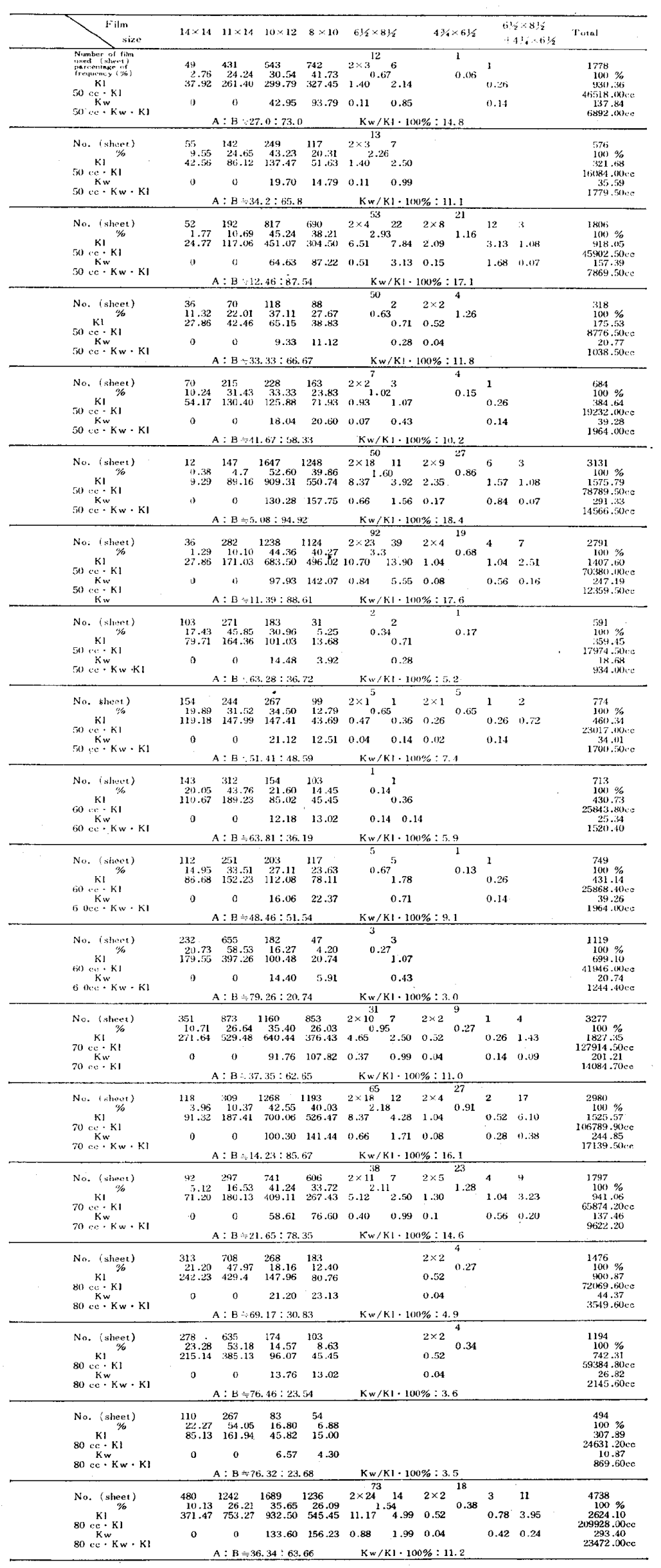

Table 5-b 
Table 4. Relation between film size and replenishment indexes.

\begin{tabular}{|c|c|c|c|c|c|c|c|}
\hline & Film size (inch) & $\begin{array}{l}\text { Film length } \\
(1 \mathrm{~mm})\end{array}$ & $\begin{array}{c}\text { Film necessary } \\
\text { to pass the } \\
\text { detector } \\
\text { (second) }\end{array}$ & $\begin{array}{l}\text { Replenishment } \\
\text { index at one } \\
\text { sheet film } \\
1 / 460 \mathrm{~mm}: \mathrm{Kl}\end{array}$ & $\begin{array}{l}\text { Film width } \\
\text { (wmm) }\end{array}$ & $\begin{array}{l}\text { Blank space } \\
\text { index } \\
\mathrm{w} / 356 \mathrm{~mm}: \mathrm{Kw}\end{array}$ & $\begin{array}{c}\text { Over-reple- } \\
\text { nishment } \\
\text { index } \\
(\mathrm{Kw} \cdot \mathrm{Kl})\end{array}$ \\
\hline \multirow{2}{*}{$\mathrm{A}$} & $14 \times 14$ & 356 & 46.4 & 0.7739 & 356 & 0 & 0 \\
\hline & $11 \times 14$ & 279 & 36.4 & 0.6065 & 356 & 0 & 0 \\
\hline \multirow{7}{*}{ B } & $10 \times 12$ & 254 & 33.2 & 0.5521 & 305 & 0.1433 & 0.0791 \\
\hline & $8 \times 10$ & 203 & 26.5 & 0.4413 & 254 & 0.2865 & 0.1264 \\
\hline & $81 / 2 \times 61 / 2$ & 214 & 27.9 & 0.4652 & $164 \times 2$ & 0.0787 & 0.0366 \\
\hline & $61 / 2 \times 81 / 2$ & 164 & 21.4 & 0.3565 & 214 & 0.3988 & 0.1422 \\
\hline & $43 / 4 \times 61 / 2 \times 2$ & 120 & 15. 7 & 0.2608 & $165 \times 2$ & 0.0730 & 0.0191 \\
\hline & $43 / 4 \times 6 \frac{1}{2}$ & 120 & 15.7 & 0.2608 & 165 & 0.5365 & 0.1399 \\
\hline & $61 / 2 \times 8^{1 / 2}+43 / 4 \times 61 / 2$ & 165 & 21.5 & 0.3587 & $214+120$ & 0.0618 & 0.0222 \\
\hline
\end{tabular}

り，フィルムの濃度曲線にも現像液の活性度の低下が現 われている。だが 2 号機では $12 / 12$ から $11 / \mathrm{V} ， 1$ 号機 では $14 / \mathrm{IV}$ から 1/VII の間ではフィルサイズB群が総現 像数に対し $50 \%$ 以下になるとフィルムの濃度低下を， $70 \%$ 以上になると濃度上昇を生じている。反面 1 号機 では25/11から21/I の間，28/I に流量計取りかえ後
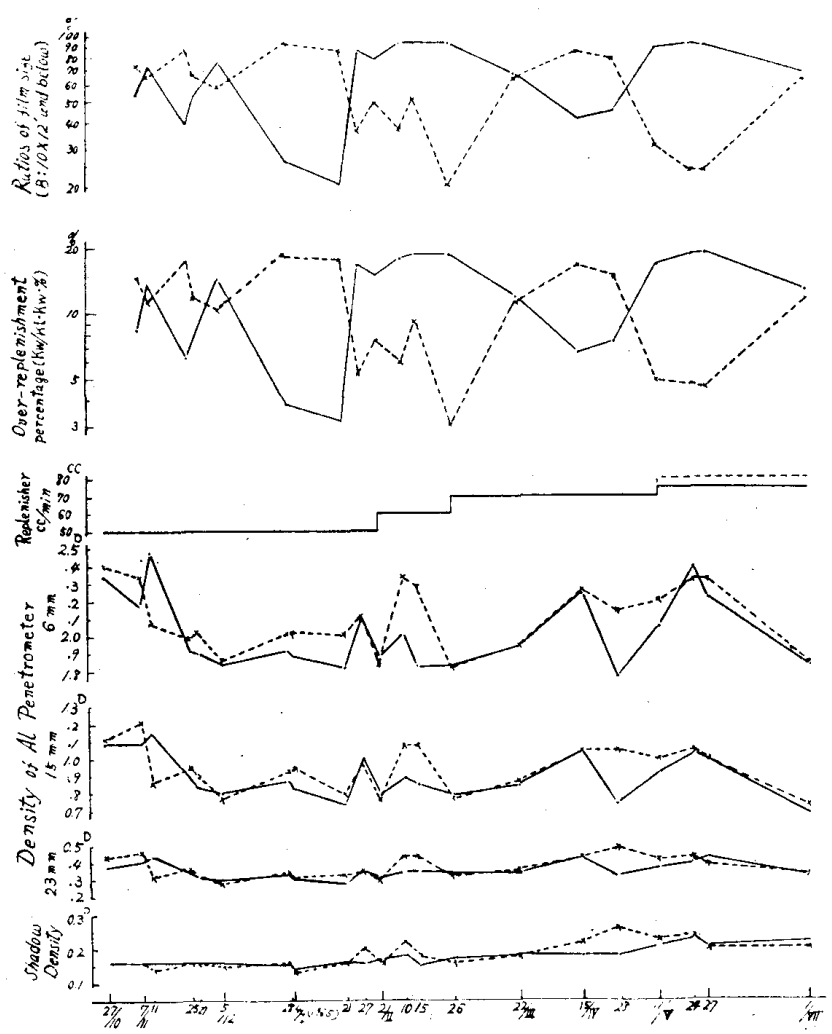

Fig. 5-a Relationship amang number of used films, ratios of replenishment and density. (observation period : Oct. 22, 1964-July 1, 1965).

$\mathrm{X}$-ray Medical automatic processer.

No. $1:-$ No. $2: \cdots \cdots$.
引続き $15 / \mathrm{IV}$ までの間，2号機では $7 / 11$ から $25 / 11$ ， 11/V から 1/VII の間のでとくピンチコックの圧力変化, 冷却水の流量の動摇に伴う温調系の不安定が原因で前記 の関係と相反した現象が生じフィルムの濃度が低下して いる．だがこれらの濃度低下は補充液の流量を増すこと なく，1，2号機相互間で現像するフィルムのサイズを調 節することで緩慢に現像効力一現像液の活性度を回復し えた。同様に過剩補充の場合です活性度を調整しえた。

また当初每分 $50 \mathrm{cc}$ に設定した補充液流量を 4 力月後 に60及び65cc に増星したのは現像の折にサイズ（A群 とB群）を調整するだけでは現像液の活性度を維持しが たかったからである。さらに $1 ， 2$ 号機で補充液の流量 に毎分 60 と $65 \mathrm{cc}$ と差を生じたのは，それぞれの流量計 の孔径の差によるものである。

以上の第 5 表 $a, b$ 及び第 5-a 図の值を要約したものが 第 6 表であり，第5-b 図は從軸にフィルムサイズ $\mathrm{B}$ 群を， 横軸に過剩補充比をとるとほぼ直線となり補充のための 係数の求め方，すなわち補充方法の妥当性を示すむので ある。

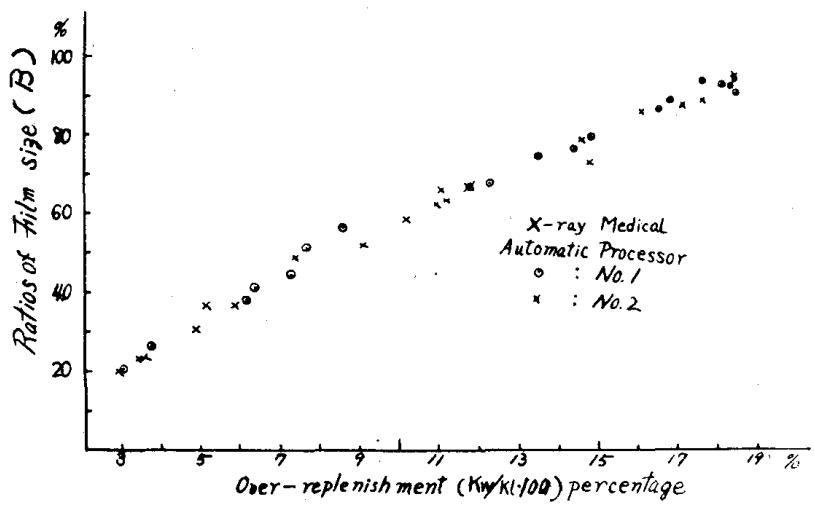

Fig. 5-b Relationship between ratio of film size and parcentage of over-replenishment. 


\section{6. 現像液の種類による影響}

\section{目的及び方法}

前項 1 から 5 までの実験は同一会社の自現機と現像液 についての検討であったが，さらにフィルム，自現機， 現像液を変えた時の検討を行なった。

結果

a ) CDM-101R と改良型 CDM-101R (CDM-101R') との比較

CDM-101R の使用温度を $20^{\circ} \mathrm{C}$ から $2^{\circ} \mathrm{C}$ ごとに $30^{\circ} \mathrm{C}$ まで変化し CDM-101R $26.5^{\circ} \mathrm{C}$ の場合と比較したむの が第 6-a 図で，CDM-101R でえた濃度曲線の低濃度側 は $\mathrm{CDM}-101 \mathrm{~K}^{\prime} .30^{\circ} \mathrm{C}$ の濃度曲線より高く, 濃度 1.55. Al $9 \mathrm{~mm}$ の点で交差し, 高濃度側では $28^{\circ} \mathrm{C}$ 現像の濃度 曲線淁近している。 $、$ は $26^{\circ} \mathrm{C}$ から $285^{\circ} \mathrm{C}$ の温度变化 の範囲で CDM-101Rは1.28から 1.60 となるが, CDM101R'では 1.41 から 1.60. Shadow density は前者で0.15 から 0.18 で岕るのが，後者は 0.16 から 0.17 と変化する 敒留まる。字た CDM-101R は $26 \pm 0.5^{\circ} \mathrm{C}, \mathrm{CDM}-101 \mathrm{R}^{\prime}$ では $28 \pm 0.5^{\circ} \mathrm{C}$ の場合の濃度変化を $\mathrm{Al}$ 階段に対する現 像温度濃度曲線上の濃度 2.0 から 0.8 の範囲で比較するる とフィルムの嶩度変化幅は前者の濃度 0.25 亿対し, 後 者は 0.20 となり，CDM-101R'は使用温度の変動注対

し CDM-101Rよりフィルムの濃度変化に及ぼす影響は 小さい.すなわち CDM-101R'は液温の変動に対する 許容度が大きいと言える。

b）現像液之自現機及びフィルムの組合せ

島津製レクトマット 3 型で CDM-3R 現像液 $(\mathrm{K})$ を使 用した時と，さくら X-レイ自現機で CDM-101R 現像

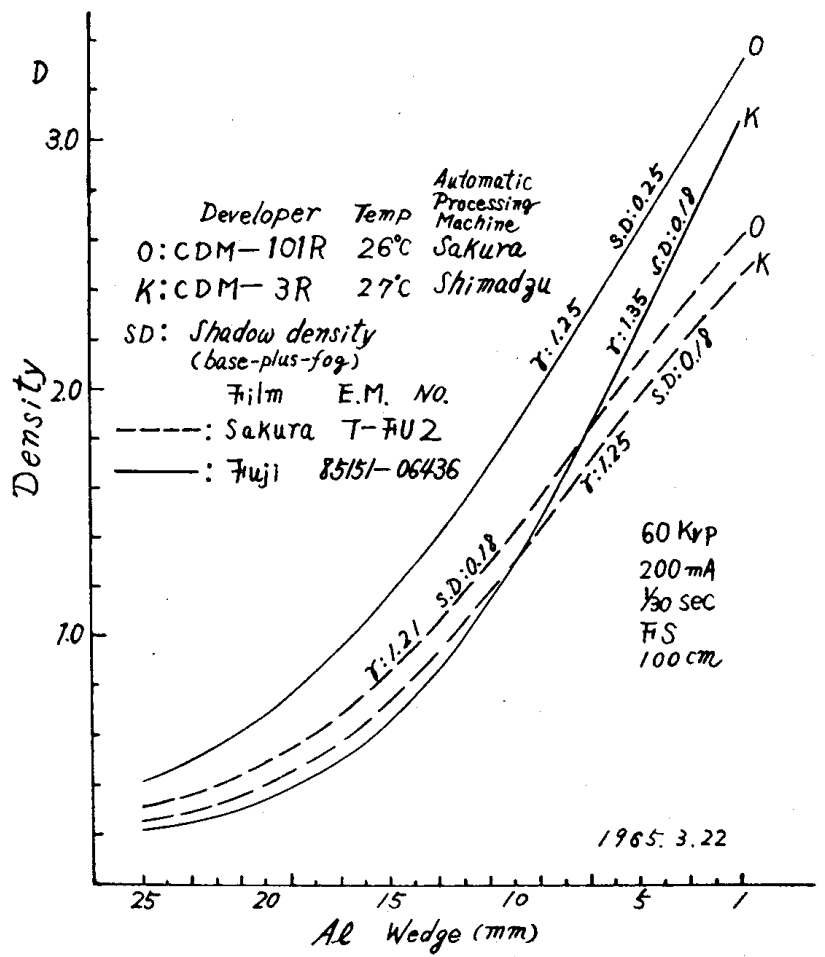

Fig. 6-b Density curve due toCDM-101R and CDM-3R developer.

液 $(\mathrm{O})$ を使用した場合について同一条件で曝射した国産 2 社のフィルム (実線之破線) の濃度曲線中濃度 2.0 か ら 0.6 の部分での $r$, Shadow density を比較したものが 第6-b 図である。また現像液，フィルム別に $\gamma$, Shadow density, Al 1，10，16，25mm の部分の濃度を要約した ものが第 7 表である．とれらの成績から破線で示すフィ ルムは現像液, 自現機が異なっ
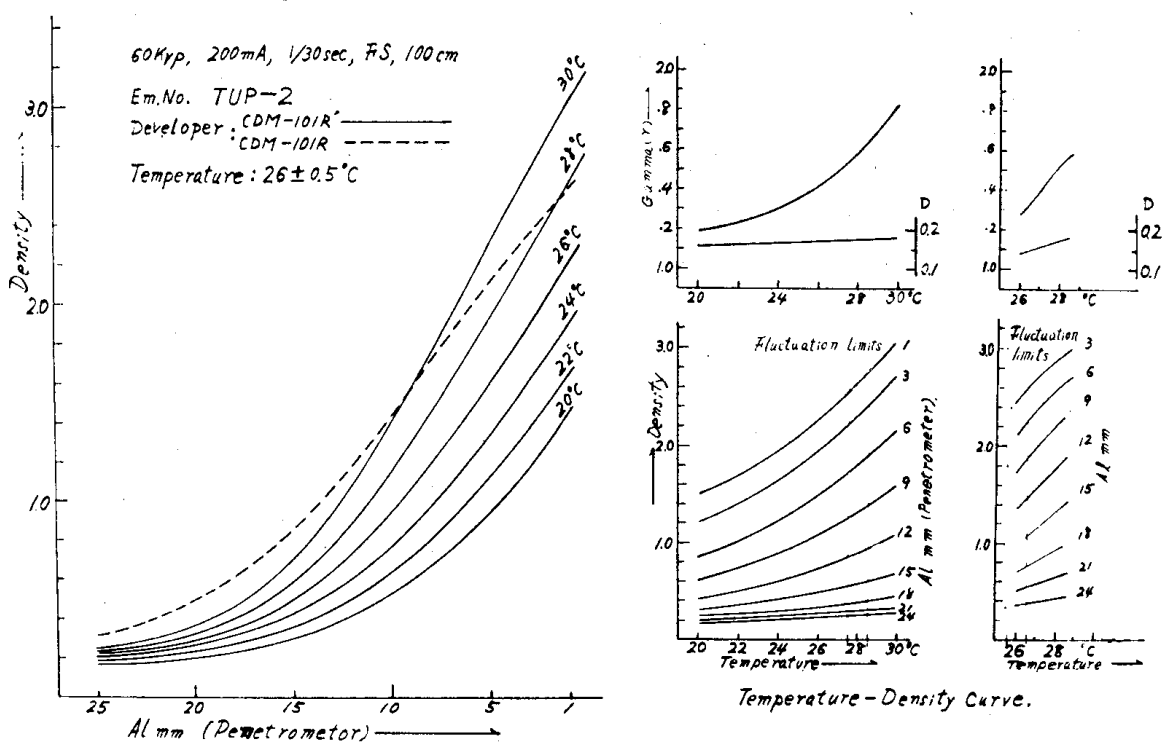

Fig. 6-a Comparison of the density curve due to CDM-101R and CDM-101R'.
ても濃度曲線に大きな差を生じ なかったが，実線で示すフィル ムは変化が著しかった。特にレ クトマット 3 型, CDM-3R で 現像したフィルム（実線K）は 他のいずれの濃度曲線とす異な った形，すなわち低濃度部の值 は低く, Shadow density 0.18 と低しにあかかわらず と高い值を示した。この現象は 第7図に示すごとく従来の国産 現像液に対する国産フィルムの 濃度曲線には認められなかった あのである。すなわち第7図に よると Rendol で現像した破線 
Table 6. Ratios of film size, ratios of replenishment and film density at the No. 1 and No. 2 automatic processer.

\begin{tabular}{|c|c|c|c|c|c|c|c|c|}
\hline & & & \multicolumn{2}{|c|}{$\begin{array}{c}\text { Rations of film size } \\
(\%)\end{array}$} & \multirow{2}{*}{$\begin{array}{l}\text { Over-replenish- } \\
\text { ment percentage } \\
(\mathrm{Kw} / \mathrm{Kl} \cdot 100 \%)\end{array}$} & \multicolumn{3}{|c|}{$\begin{array}{c}\text { Density } \\
\mathrm{Al} \text { penetrameter }(\mathrm{mm})\end{array}$} \\
\hline & & & A & B & & 23 & 15 & 6 \\
\hline \multirow{6}{*}{$\begin{array}{l}\text { X-ray Medical } \\
\text { Automatic } \\
\text { Processor }\end{array}$} & \multirow{3}{*}{ No. 1} & \multirow{3}{*}{$\begin{array}{l}\text { minimum value } \\
\text { mean value } \\
\text { maximum value }\end{array}$} & 6.29 & 20.83 & 3. 10 & 0.28 & 0.69 & 1.82 \\
\hline & & & 32.53 & 67.46 & 12.32 & 0.35 & 0.89 & 1. 997 \\
\hline & & & 79.63 & 93.07 & 18.40 & 0.44 & 1.15 & 2. 48 \\
\hline & \multirow{3}{*}{ No. 2} & \multirow{3}{*}{$\begin{array}{l}\text { minimum value } \\
\text { mean value } \\
\text { maximum value }\end{array}$} & 5.08 & 20.74 & 3.0 & 0.28 & 0.73 & 1.82 \\
\hline & & & 42.26 & 57.73 & 10.34 & 0.376 & 0.94 & 2.09 \\
\hline & & & 79.26 & 94.92 & 18.40 & 0.49 & 1. 22 & 2. 34 \\
\hline
\end{tabular}

Table 7. Density due to CDM-101R and CDM-3R developer.

\begin{tabular}{c|c|c|c|c|c|c|c}
\hline \multirow{2}{*}{ Developer } & Film & S.D & $\gamma$ & \multicolumn{4}{|c}{ Al Wedge (mm) } \\
\hline & & & & 1 & 10 & 16 & 25 \\
\hline CDM-101R & $\ldots$ & 0.25 & 1.25 & 3.34 & 1.89 & 1.06 & 0.41 \\
& $\ldots .$. & 0.18 & 1.21 & 2.59 & 1.57 & 0.76 & 0.30 \\
\hline & & 0.18 & 1.35 & 3.11 & 1.52 & 0.66 & 0.22 \\
CDM-3R & $\ldots \ldots .$. & 0.18 & 1.25 & 2.46 & 1.46 & 0.57 & 0.26 \\
& & & & & & &
\end{tabular}

で示すフィルムの濃度曲線は実線のむのと近似した值を 示しているが, Shadow density は 0.18 亿対し 0.24 と 高くなっている. CDXの場合は「フィルムと現像液は 同一メーカーのものを」の提言のごとく笑線の方は破線
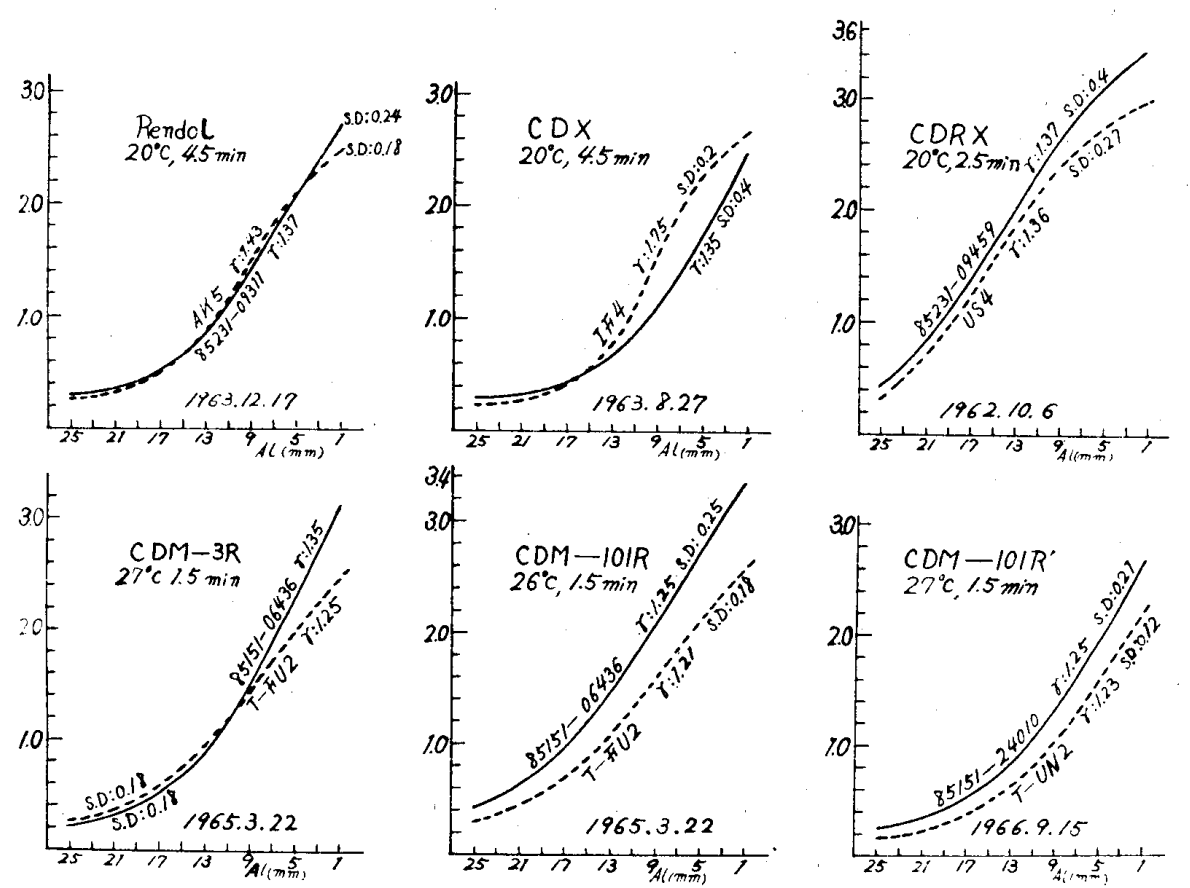

Fig. 7 Comparison of density curve due to various developer $(60 \mathrm{kVp}, 200 \mathrm{~mA}, 1 / 30 \mathrm{sec}, 100 \mathrm{~cm}$ screen : Fs).
のものより濃度は低く，かつ Shadow densityは 0.2 に 対し 0.4 と高く, $\gamma$ は 1.75 に対し 1.35 と低くなって いる。また CDRX では $\gamma$ はほぼ似た值を示すが濃度は 破線の方が低く，Shadow densityは 0.27 に対し 0.4 とやはり高くなっている。CDM-101R 及び 101R'の 場合はいずれも実線で示すフィルムが濃度, $\gamma$, Shadow density のいずれあ高い值を示している。しかしながら CDM-3R を用いると低濃度側は実線で示すむのの方が 破線のものより低く, Shadow densityはいずれも 0.18 であるが高㧼度側では破線で示すフィルムの場合より高 い值を示し，当然 $\gamma$ も高く先に述べたどの現像液を倣い た場合にもなかった現像效果がみられた。

\section{III. 総括並びに考案}

1. ローラ一型自動現像機に CDM-101R 現像液を用い 26.5 ${ }^{\circ} \mathrm{C} ， 1.5$ 分現像したときの濃度 曲線はハンガー型自動現像機に CDRX 現像液を用い2 $20^{\circ} \mathrm{C} ， 2$ 分40秒現像をしたすのととはほ ぼ近似しているが低濃度側はや や高く，高濃度側は低くなり， Shadow density む後者の 0.12 に対して0.16己なるのは短時間 処理を目的として高温現状では 一応やむをえ現象とあ考え られるが奉験 6 の項に述べた CDM-3R 現像液のどとく，そ の処方如何によってはさらに Shadow density を抑え，高濃 度部を上昇させるように改善す ることあ可能と考えられる。し かしながら CDM-101R 現像液 
では $26.5^{\circ} \mathrm{C}$ に現像液温度を保つだけでハンガー型自動 现像機で CDRX 現像液を使用していたときの撮影条件 を変更することなくローラ一型自動現像機の使用に移行 できた。

2.ローラー型自動現像機の循環ポンブを停比した状 態で見像液用ラックを通過させてフィルムを现像する， すなわち，ローラーの圧迫と $26.5^{\circ} \mathrm{C} の$ 温度で 1.5 分現 像をしたときの濃度曲線は同じ温度，現像液のタンク現

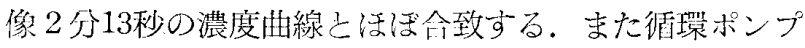

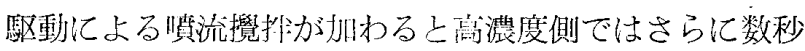
の, 荹度 0.8 以下の低涨度㒋では濃度の低い部分ほど大 きく現像の進行が琹めらる。ローラーの在迫で約43秒の 現像时閒の延長に相当する現像の進行を生じ，さらに唺 環ポンプの駆動による櫴流筧找で約 10 秒の現像時間延舆 に相当する效果が諗められた。

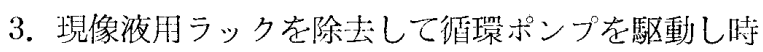
間归像を行なうと高照度になる活じ，また現像時閒の厓 くなるほど著明な現像の進行が見られる。従米一般に 1-phenyl 3-pyrazolidon を主戍としたいわ印る $\mathrm{PQ}$ 现 像源では $M Q$ 現像液のごとき攪挥効果は望めないとい

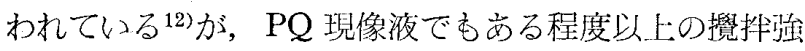
度では㩭抖効果 ${ }^{6}$ が生ずるととが認められた。 との濆流 攪抖吼は現像液用ラックの装着で著しく弱められるが, 喷出目側では依然として攪排效果を与えるだけの強度が 㒀在するために奏験 2 に示したじとくフィルムの噴出曰 側では反対側の部分より10〜20秒間現像特間を延辰した のに相当した現像の進行を生ずる. これを濃度で示すと 高濃度側で 0.5 , 低濃度側で 0.25 程度の動摇を濃度曲線 上に生ずるととを意味し，現像液管理用フィルムを現像 する場会にその挿入方问を一定にしないと䟴度曲線の足 または局の部分に影響し，測定䛊差の因子となる。ゆえ に㧓環ポンプ嘖任口を 1 カ所に設けている現在の機棈を 改めスプリンクラーのごとき細孔化，分散化をすること が必要と慙われる。すなわちいわ机る $\mathrm{PQ}$ 現像液の場 合でも現像液の攪拌強度はフィルムの濃度曲線の形を左 右する大きな因子で，無視でき好存在である。

4. 循環ポンプ系液用フィルターは $10 \times 12$ 时フィルム 20,000 枚程度の現像で約 40〜 50g の重量増加となるが フィルター使用開始時，および打切時のフィルム浱度曲 線上では差が楒められなかった。 反って補充の不適当さ から坐ずる現像液の沾性度の動摇の方が強く現われた。 すなわち $10 \times 12$ 时フィルム 20,000 枚まではフィルター を取換えなくてもフィルム濃度曲線上には認めるべき变 化は現われない。またフィルターの重量は $10 \times 12$ 吋フィ
ルム 300 枚で約 $1 \mathrm{~g}$ 增加するが，なお現像液の混濁や現 像没槽内部, 現像液用ラックなどに沈湟固着の生ずるこ とから現在使用中のフィルターは根本的に改める必要が ある。

5. 補光液の流量は明ら加現像效果を左在するもの であるが，フィルムが検出ラックを通過する間だけ補充 涖が流大するる捨制補充法では現像するフィルムサイズが 一定しないため現像液の疫当と補允による回復の関係を 一定に保つととは至難であり，シネフィルムの自動現像 の場合のごとく精度の高い現像液の管理は望めない. 每 分 $60 \sim 65 \mathrm{~m} l$ の補充を行なう場合には $10 \times 12$ 时サイズ以 下の現像枚数が全体の50\%以下になると補充不足となり 濃度低下を生じ，70\%以上になると濃度上昇をみる。し たがって日々の総現像枚数に対する $10 \times 12$ 吋サイズ以下 の現像枚数を考慮して補允液流量を設定する必要がある. 莧状では撮影部位すなわち画質に上る現像淮の疫等の姜 までは検比できない。

6. 現像液の種額によってフィルムの濃度曲線が大き く左右されるのは当然であり，征米市販されていた現像 液ではShadow density の高くなるフィルムでもCDM3R のごとく，その処方如何によっては永 $\gamma$ を保ちつつ Shadow density を低くすることもできる。また必ずし む同一メーカーのフィルムと現像淮を使用するととが最 良の結杲を得る方法であないことが解った。

\section{む す び}

以上のごとく国座ローラー型自動現像機について現場 の者の立場から可能な範囲で現像液の管理上必要々思わ れる諸因子について検狳したが，な打多くの未着手の間 題もあり, さらにこの方面の発達は著しく 3.5 分現像, 90秒現像装置の戔用化, 補光液の調節機構の改善などわ れわれの笑験中に続々と進歩, 改善が行なわれている. これらについても同椂に検討すべきであるが一応ことで 今までの成果を縓姺彗諸见ので指導，で批判を仰ぐ 次第である。

稿を終るに当たりご校閲を賜わった放射線部部長平松 教授，ご指導，ご緶撻下さった副部長吕村利雄助教授, ならびに島津製レクトマット 3 型の使用を快くお許しく ださりまたで拹力くださった国立金沢病院の越村与阳男 技師言，同技師各位，および当放射線部松田技師長，南 現像主任のご寛容に心からの謝意を呈します。

なお全く未知の著者らを現像処理の㑭界で先達となっ てで指導いただいたた故三上徹吉先輩の霊にささやかなが らこの論文を捧げまず。 
（本諭文の要旨は第20回，第21回日本放射線技術等会 総会，抢よび第 1 回，筙 2 回日本湤射線技術学会東河北 陸部会に発表した。）

\section{参考交献}

1）内滕毫親他：白動現像这びにタンク現像について, 口放技誌。18卷。2 奇.

2) B. J. XXVI. August. 1953.

3）藤沉 信編：写真の進歩. 1951〜1964. 富士写真フ イルム $\mathrm{KK}$.

4) Von J. Franzen : Zur maschinellen Verarbeitung von Röntgenaufnahmen. Fortschr. Röntgenstr. 92. [1960] 4 .

5）螎术卓四郎：ポジフィルムの迅速処理法。日写誌， Vol. 22, No. 1, 1959.

6）荻池真一他：現像の理諭上垁際。アルス学真科学蒜 書。第 3 版， 1954 .

7）科学写真使覧(中)，如善，1959.
8) 第 1 回日本写龺学会清翼会資料. 日本写真学会編. 1956.

9）蒌池真一他：バナジウムによる迅速現像法(第 1 報), 日写誌, Vol. 19, No. 1, 1956.

10）北川卓四郎他：バナジウム現像のテレビションへの 応用. 日写誌。Vol. 20, No. 2, 1957,

11）菊池真一他：迅速定着汇関する研究，日写衿，Vol. 18, No. 2 3, 1955.

12) 中村泰三: $\mathrm{PQ}$ 現像液の合理的な暗室操作とは, 写 真サロン, Vol. 27, No. 6, 1956.

13) Charles. J. Kunz and H. D. Russell : A Self-Threading Processor and Dryer for Use with Specific Sheet Film. Phot. Sci. and Emg., Vol. 3, No. 1, 1959.

14）小林義知：よい $\mathrm{X}$ 線写真はどうして得られるか。小 西六学術講演会資料。1962.

15）松田他：国産自動現像装置について。日放技誌，18 巻， 2 㫔.

\section{新 発 売 \\ Conbe-PHANTOM $-\mathrm{Mix}-\mathrm{D}$ 相当品一}

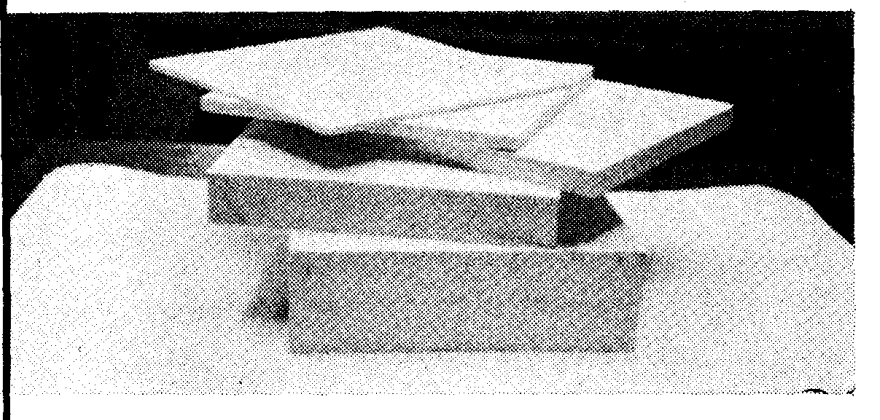

[種 類]

$300 \times 300 \times 200 \mathrm{~m} / \mathrm{m}$ $300 \times 300 \times 10^{\mathrm{m} / \mathrm{m}}$ $300 \times 300 \times 20 \mathrm{~m} / \mathrm{m}$ $300 \times 300 \times 300 \mathrm{~m} / \mathrm{m} \quad 300 \times 300 \times 40 \mathrm{~m} / \mathrm{m}$ 此の他特注サイズ可能 $300 \times 300 \times 80^{\mathrm{m} / \mathrm{m}}$

今度販売致しましたコンビーファントムはMix一D PHANTOM と相当する もので有り、人体組成に殆んど近い性能を発揮し学会でも注目をあびて居る製 品です。 詳細について下記へ連絡下されば資料を送附致します。

製造発売元

\section{三和電工株式会社}

TE L （06）322-2301(代）プラスチック部 